\title{
Studies of Human Sera with Cytotoxic Activity
}

\author{
Ralph C. Williams, Jr., Jean D. Emmons, and Edmond J. Yunis \\ From the Arthritis Unit, Department of Medicine, University of New Mexico \\ School of Medicine, Albuquerque, New Mexico, 87106, and Department of \\ Laboratory Medicine, University of Minnesota Hospitals, \\ Minneapolis, Minnesota, 55455
}

\begin{abstract}
A B S T RAC T 42 human sera showing in vitro cytotoxic activity of restricted or broad HL-A specificities with test human lymphocytes were studied for the molecular and immunoglobulin class of cytotoxic antibody using sucrose gradient separations, DEAE-cellulose chromatography, and Sephadex G-200 gel filtration. Sera originated from patients with previous multiple pregnancies (19), multiply transfused patients (8), subacute bacterial endocarditis (4), systemic lupus (2), and human umbilical cord sera (9). In 32 of 42 instances, predominant cytotoxic activity was found in high molecular weight gradient fractions; however, DEAE chromatographic separations revealed cytotoxic activity in initial buffer fractions containing primarily $\gamma \mathrm{G}$ globulin. Gradient separations of cytotoxic activity within initial $\gamma \mathrm{G}$ DEAE fractions showed localization of cytotoxicity only in high molecular weight materials. Confirmation of high molecular weight $\gamma \mathrm{G}$ cytotoxic activity was obtained by resistance to mercaptoethanol treatment, abolition of activity after absorption only with specific anti- $\gamma \mathrm{G}$ antisera, and by the finding that high molecular weight cytotoxic activity in gradients or gel filtration run at neutral $\mathrm{pH} 7.4$ became $7 \mathrm{~S}$ when separations were rerun at an acidic $\mathrm{pH}$ of 4.0 . Such $7 \mathrm{~S}$ activity again became rapidly sedimenting when the same fractions were again rerun in gradients at neutral $\mathrm{pH}$.

19S $\gamma \mathrm{M}$ cytotoxic activity was documented in a panel of 15 human sera containing anti-" $\mathrm{I}$ " cold agglutinins. In this instance the cytotoxic activity appeared to be related to the cold agglutinin antibody since it was mercaptoethanol sensitive and could be demonstrated in monoclonal antibody eluates containing primarily $\gamma \mathrm{M}$.
\end{abstract}

This work was supported in part by grants AM AI 13824-01 and AM 13690-01 from The United States Public Health Service.

Received for publication 28 December 1970 and in revised form 24 February 1971.
No in vitro protection again cytotoxic effect was demonstrated when isolated human 19S anti- $\gamma$-globulins were aded to the lymphocytotoxic assay system.

With the exception of cold agglutinins, human cytotoxic antibodies appear to be primarily $\gamma \mathrm{G}$ producing in vitro lymphocyte killing either as $7 \mathrm{~S} \gamma \mathrm{G}$ globulin or as rapidly sedimenting aggregates or complexes of $\gamma \mathrm{G}$ molecules.

\section{INTRODUCTION}

Human sera showing broad or sharply limited cytotoxic activity for human lymphocytes of various HL-A types have provided essential reagents for the study of histocompatibility typing in many laboratories. Several recent reports have indicated that human sera containing cytotoxic antibodies active in the presence of complement may be associated with various connective tissue disorders-most predominantly those associated with diffuse vasculitis as in systemic lupus (1-3) or periarteritis nodosa (4). Little is known about the exact pathogenic significance of human cytotoxic antibodies per se and little information is available concerning the immunoglobulin distribution or molecular class of such human antibodies (5). Accordingly, we have examined a series of human sera chosen so as to contain cytotoxic antibodies to well-defined HL-A antigens. With the exception of $7 \mathrm{~S} \gamma$-globulin cytotoxic antibodies found in some human sera, most of the human cytotoxic antibodies we have characterized to date appear predominantly to be rapidly sedimenting or high molecular weight $\gamma \mathrm{G}$. 19S $\gamma \mathrm{M}$ cytotoxic antibodies have also been documented in sera containing cold agglutinins. The biologic implications of this finding are of considerable and potential interest since it appears that complexes or aggregates of $\gamma \mathrm{G}$ molecules sedimenting as high molecular weight materials are responsible for the cytotoxic activity detected in many human sera.

1514 The Journal of Clinical Investigation Volume 501971 


\section{METHODS}

A panel of sera showing consistent cytotoxic antibody for lymphocytes previously typed for HL-A antigens were selected for study. These human sera were largely derived from five major sources: (a) grand multiparous women previously sensitized by multiple pregnancies (19 sera); (b) 8 sera obtained from patients who had received multiple transfusions; (c) 5 sera derived from patients with disseminated lupus erythematosus or diffuse vaculitis; $(d) 15$ sera from patients with cold agglutinins associated with viral pneumonia or chronic cold agglutinin disease; and (e) 4 sera from patients with subacute bacterial endocarditis.

Cytotoxicity was tested using the microdroplet method of Terasaki (6) in disposable plastic trays after addition of test lymphocytes, human serum, or isolated serum fractions, and complement source. Cytotoxicity was read by counting percentages of test cells which took up eosin $\mathrm{Y}$ stain after incubation of test mixtures for $1 \mathrm{hr}$ at $22^{\circ} \mathrm{C}$. The recent modification suggested by Terasaki, Mottironi, and Barnett (3) of incubation at $15^{\circ} \mathrm{C}$ was not used since, in our hands, this sometimes resulted in death of control test cells alone without addition of serum, and was not found to be suitable for this study.

Test lymphocytes utilized in the cytotoxicity panel constituted a panel of 30 individual lymphocytes which included most of the well-defined HL-A types as recognized by HL-A-typing antisera defining 15 specificities.

A consecutive series of 297 cord blood samples obtained from the obstetrical service of the Bernalillo County Medical Center, Albuquerque, N. Mex., were also screened for cytotoxic antibodies. Of these sera, $12(6 \%)$ were found which contained definite reproducible, complement-dependent cytotoxic activity.

Physical studies involving separation of $19 \mathrm{~S}$ or high molecular weight and 7S fractions of cytotoxic sera utilized overnight sucrose density gradient separation (7). 20-30 fractions were collected from the bottom or top of the tube, the protein curves were determined by the Folin technique, and individual fractions were tested for cytotoxic antibody activity. Immunoglobulin distribution of gradient fractions was determined by immune diffusion in agar gel, specific inhibition of agglutination of erythrocytes tanned with isolated immunoglobulins in the presence of monospecific antiimmunoglobulin antisera, and by disappearance of cytotoxic antibody activity after absorption with specific antisera to $\gamma \mathrm{G}, \gamma \mathrm{A}, \gamma \mathrm{M}, \gamma \mathrm{D}$, or $\gamma \mathrm{E}$.

In most instances, DEAE-cellulose separations of serum fractions using four stepwise buffers of $\mathrm{pH} 6.3,0.015 \mathrm{M}$; $\mathrm{pH}$ 6.0, $0.04 \mathrm{M} ; \mathrm{pH} 5.8,0.1 \mathrm{M}$; and $\mathrm{pH} 5.5,0.3 \mathrm{M}$ phosphate buffers, were used $(8,9)$ for isolation of cytotoxic antibody fractions.

Because high molecular weight fractions of both adult and some human cord blood sera seemed to show a high association with cytotoxic antibody, mercaptoethanol treatment of whole sera (10) was also utilized to differentiate sulfhydryl-sensitive cytotoxic antibody (19S $\gamma M$ ) from rapidly sedimenting complexes of $\gamma \mathrm{G}$ antibody showing cytotoxic activity.

\section{RESULTS}

Studies of cytotoxic antibody in sera from patients with multiple transfusions, multiple pregnancies, subacute bacterial endocarditis, and systemic lupus. The primary finding emerging from this study was the pre-
TABLE I

Molecular Class and Specificity of Cytotoxic Antibodies in Various Human Sera as Studied by Sucrose Density Gradient Separation

\begin{tabular}{|c|c|c|}
\hline Patients & $\begin{array}{l}\text { Molecular class by } \\
\text { sucrose gradient }\end{array}$ & HL-A specificity \\
\hline \multicolumn{3}{|c|}{ I Immunized by pregnancy } \\
\hline 1. Dah. & $\mathrm{HMW}^{*}$ & Multiplef \\
\hline 2. $\mathrm{Hr}$. & $\mathrm{HMW}^{*}$ & Multiple \\
\hline 3. War. & $\mathrm{HMW}^{*}$ & Multiple \\
\hline 4. Denn. & $\mathrm{HMW}^{*}$ & Multiple \\
\hline 5. Sand. & $\mathrm{HMW}^{*}$ & Multiple \\
\hline 6. Bra. & $\mathrm{HMW}+(7 \mathrm{~S})$ & $10,11,+$ Te 51 \\
\hline 7. Le $\mathrm{Pa}$. & $\mathrm{HMW}+(7 \mathrm{~S})$ & $1,11,8$ \\
\hline 8. Klae. & $\mathrm{HMW}+(7 \mathrm{~S})$ & Multiple \\
\hline 9. Salt. & HMW* & 2 \\
\hline 10. Tisch. & $\mathrm{HMW}^{*}$ & 2 \\
\hline 11. Sav. & HMW* & 2 \\
\hline 12. Try. & $\mathrm{HMW}+(7 \mathrm{~S})$ & 7 \\
\hline 13. Koeh. & $\mathrm{HMW}+7 \mathrm{~S}$ & 7 \\
\hline 14. Lewand. & HMW $^{*}$ & 1 \\
\hline 15. Cosk. & HMW* $^{*}$ & 7 \\
\hline 16. Byr. & $\mathrm{HMW}+(7 \mathrm{~S})$ & 5 \\
\hline 17. Grub. & $\mathrm{HMW}+(7 \mathrm{~S})$ & 9 \\
\hline 18. John. & HMW + (7S) & 8 \\
\hline 19. Ott. & $\mathrm{HMW}+(7 \mathrm{~S})$ & 12 \\
\hline
\end{tabular}

II Multiply transfused $(14 / 16+)$
1. S. W.
$\mathrm{HMW}^{*}$
2. A
$\mathrm{HMW}^{*}$
3. $\mathrm{K}$
4. $\mathrm{E}$
$\mathrm{HMW}^{*}$
HMW* $^{*}$
5. D
$\mathrm{HMW}^{*}$
6. Q
$\mathrm{HMW}+7 \mathrm{~S}$
7. $\mathrm{O}$
$\mathrm{HMW}+7 \mathrm{~S}$
8. $\mathrm{F}$
$\mathrm{HMW}^{*}$

\begin{abstract}
Multiple
Multiple

Multiple

Multiple

Multiple

Multiple

Multiple

Multiple
\end{abstract}

III With subacute bacterial endocarditis $(4 / 53+)$
1. Dald.
$\mathrm{HMW}+7 \mathrm{~S}$
2. John.
$\mathrm{HMW}^{*}$
3. Frid.
$\mathrm{HMW}^{*}$
4. McKer
$\mathrm{HMW}+7 \mathrm{~S}$
$70 \%$
$70 \%$
$50 \%$
Multiple

IV With SLE (5 of $13+$ )
1. Herr.
$50 \%$
$20 \%$
2. Smi.
$7 \mathrm{~S}$

V Human cord sera
1. $\mathrm{K}-2$
2. $\mathrm{K}-37$
3. $\mathrm{Gu}$.
$\mathrm{HMW}^{*}$
4. Sc.
5. Al.
6. $\mathrm{K}-93$
7. $\mathrm{K}-103$
8. $\mathrm{K}-215$
9. $\mathrm{K}-185$

HMW $+7 S$
$7 S$
$7 S$
$7 S$
HMW*
HMW $^{*}$
HMW $^{*}$
HMW $^{*}$
$25 \%$
HL-A 9
$30 \%$
$45 \%$
$20 \%$
HL-A 1
HL-A 1, 7, 9, 12
$75 \%$
$83 \%$

† Sera classified as multispecific showed cytotoxic reactivity with over 90 per cent of the 30 individual lymphocytes used for testing.

\$ Percentages given indicate percentage of 30 individual test cells showing cytotoxic reactions with given serum.

* High molecular weight or rapidly sedimenting activity. 


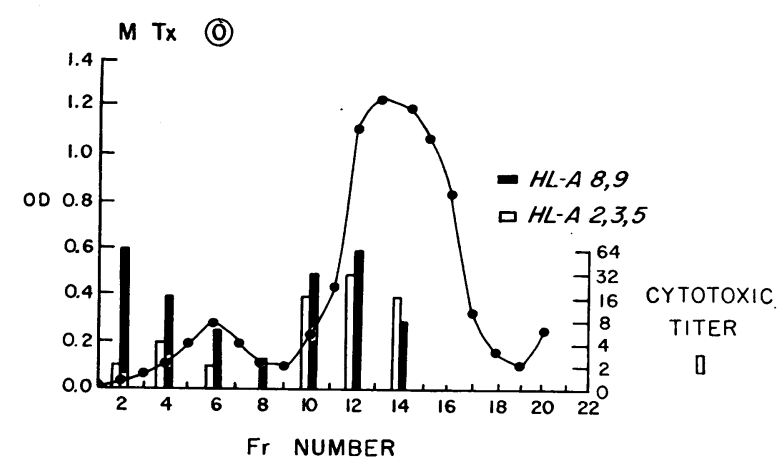

Sav M. Preg.

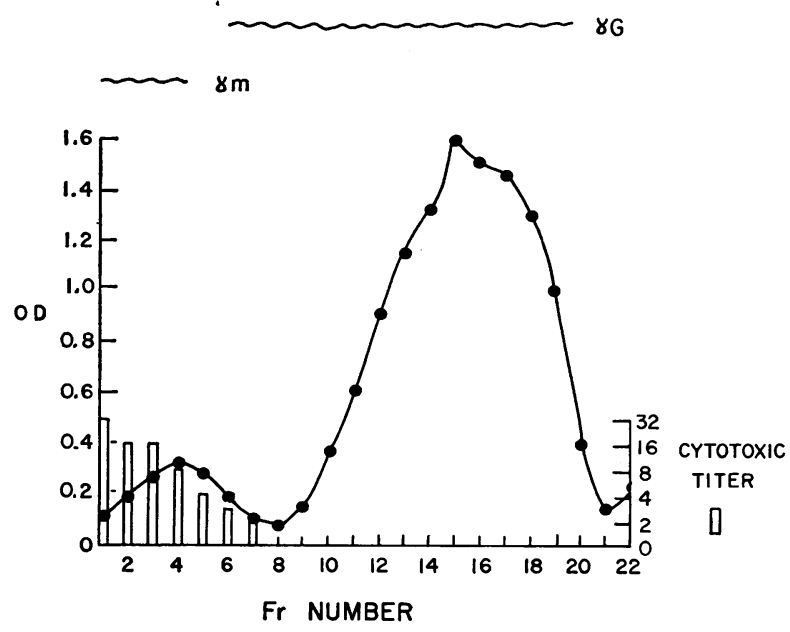

Figure 1 A. Sucrose gradient separation of serum $O$ from patient who had received multiple transfusions. Bottom of gradient (high molecular weight fraction) to left and top of gradient to right. This serum contained cytotoxic antibody activity in both high molecular weight and $7 \mathrm{~S}$ regions when tested against five individual donor lymphocytes possessing HL-A specificities 8, 9, 2, 3, and 5. Approximately equal cytotoxic titers in $19 \mathrm{~S}$ and $7 \mathrm{~S}$ fractions were noted in 7 of 42 sera (Table I) studied after gradient separation. B. Sucrose gradient separation of serum Sav. from patient with multiple pregnancies. This serum showed clear-cut specificity for HL-A 2 lymphocytes. All cytotoxic activity was demonstrated in high molecular weight fractions 1-7. Immune diffusion of individual gradient fractions showed $\gamma \mathrm{M}$ in $\mathrm{Fr}$. 1-4 and $\gamma \mathrm{G}$ in Fr. 6-21; however, inhibition experiments utilizing specific anti- $\gamma \mathrm{G}$ antiserum and cells tanned with $\gamma \mathrm{G}$ globulin indicated $\gamma \mathrm{G}$ globulin in Fr. $1-5$ as well. 32 of 42 sera listed in Table I showed predominant high molecular weight cytotoxicity in similar gradient separations.

dominant high molecular weight cytotoxic activity documented in 32 of the 42 sera analyzed by density gradient separation. A summary of the results of sucrose gradient separations performed on these sera is shown in Table I. The molecular distribution of cytotoxic antibodies appeared to bear no distinct relationship to HL-A specificities of individual sera. When high molecular weight cytotoxic antibody predominated, the $7 \mathrm{~S}$ activity is indicated in parentheses (7S) whereas when cytotoxic activities in $7 \mathrm{~S}$ and high molecular weight fractions were equivalent, no parentheses are shown in Table I.

In the case of sera showing multi-specific reactivities against many cells of different HL-A types, a panel of five diverse lymphocyte types were tested against separated gradient fractions.

Of interest was the finding of four strongly cytotoxic sera among a group of 53 patients with subacute bacterial endocarditis tested. Three of these four patients had never received transfusions or undergone pregnancy at the time the sera were collected. Also of note were the five cord sera which contained predominant high molecular weight cytotoxic antibody activity. None of these infants subsequently has shown evidence of perinatal morbidity or congenital abnormality.

In many instances cytotoxic activity was noted among 7S gradient fractions, but highest titers of specific cytotoxic antibody were predominantly localized to the high molecular weight fractions. Representative gradient separations illustrating these findings are shown in Figs. $1 \mathrm{~A}$ and $1 \mathrm{~B}$. Because of the marked preponderance of high molecular weight cytotoxic antibody activity in most experiments, some question arose as to whether the primary method of molecular class separation had induced some sort of artifactual bias. Accordingly, five normal sera, devoid of intrinsic cytotoxic activity in whole unfractionated state, were subjected to sucrose gradient separation to insure that the separation of high molecular weight fractions from such normal sera did not in itself induce cytotoxic activity. In such experiments no such activity was noted in any of the normal sera thus separated. In addition, active high molecular weight sucrose gradient fractions dialyzed extensively against several changes of phosphate buffer $\mathrm{pH} 7.4,0.1$ M showed no diminution of cytotoxic activity.

A second approach was used next to define the type of immunoglobulin class of human cytotoxic antibodies among all of the sera listed in Table I. DEAE fractionation using four stepwise buffers indicated virtually all activity to be within the first peak which contained only $\gamma \mathrm{G}$ when concentrated and examined by immunoelectrophoresis (Figs. $2 \mathrm{~A}$ and $2 \mathrm{~B}$ ). This discrepancy was a surprising circumstance and indicated that although cytotoxic activity sedimented within the high molecular weight fractions, it consistently appeared to be concentrated in fractions eluted with the first DEAE-buffer $\mathrm{pH} 6.3,0.015 \mathrm{M}$, which contained $\gamma \mathrm{G}$ and no detectable $\gamma \mathrm{M}$. Accordingly, initial DEAE fractions from such sera were analyzed by sucrose gradient separation. In all instances the cytotoxic activity appeared at the bottom of the gradient, representing a small fraction of the total protein applied to the density gradient separa- 
tion (Fig. 3). Specificity for HL-A test lymphocytes similar to that present in whole serum was retained.

At this juncture, several possibilities were considered: (a) rapidly sedimenting cytotoxic activity within the human sera fractionated by sucrose gradient might exist as antigen-antibody complexes of $\gamma \mathrm{G}$ and circulating HL-A antigen; (b) the cytotoxic effect demonstrable in such sera was dependent upon high molecular weight complexes of $\gamma \mathrm{G}$ molecules; or (c) cytotoxic antibody activity was represented by a distinct subclass of immunoglobulins which were not $\gamma \mathrm{M}$ and perhaps not $\gamma \mathrm{G}$ but whose charge properties resulted in elution with the first DEAE buffer generally regarded as producing relatively pure $\gamma \mathrm{G}$ by this technique of chromatographic separation $(8,9)$.

A series of experiments were next designed to answer the questions posed above. A group of sera were chosen which showed the cytotoxic activity only in high molecular weight gradient fractions but in initial peaks of DEAE separation. When the cytotoxic first DEAE peaks consisting of only $\gamma \mathrm{G}$ were dialyzed against $\mathrm{pH}$ 4.0, $0.1 \mathrm{~m}$ acetate buffer and run over a Sephadex G-200 column (Pharmacia Fine Chemicals Inc., Uppsala, Sweden) equilibrated with the same acidic buffer, a protein curve falling within the $7 \mathrm{~S}$ region was obtained as determined by $7 \mathrm{~S}, 11 \mathrm{~S}$, and $19 \mathrm{~S}$ markers (11). After fractions were dialyzed back to neutrality $(\mathrm{pH}$ $7.4,0.1 \mathrm{M}$ phosphate buffer), the cytotoxic antibody activity was detected only in $7 \mathrm{~S}$ regions. The same type of experiment was performed using sucrose gradients made in $\mathrm{pH}$ 4.0, $0.1 \mathrm{M}$ acetate buffer. When initial DEAE peaks containing cytotoxic activity were simultaneously run in the same gradient experiment, the fractions separated in acid milieux showed cytotoxic antibody activity (after dialysis to neutral $\mathrm{pH}$ ) only in $7 \mathrm{~S}$ regions. On the contrary, the same gradient separation run at neutral $\mathrm{pH}$ showed only rapidly sediment-

FIgURE 2 A. DEAE-cellulose chromatographic separation of serum Sav. (separated on gradient Fig. 1 B) using four stepwise buffers. All cytotoxic activity against several HL-A test lymphocytes was concentrated in first two buffer peaks ( $\mathrm{pH} 6.3,0.015, \mathrm{M}$ and $\mathrm{pH} 6.0,0.04, \mathrm{M}$ phosphate buffers). $B$. When the 4 individual peaks from DEAE separation shown in Fig. $2 \mathrm{~A}$ were concentrated to volume equal to starting volume of serum, immunoelectrophoresis against anti-whole serum (AWS) showed only $\gamma \mathrm{G}$ globulin in peak obtained with $\mathrm{pH} 6.3,0.015$, $\mathrm{M}$ buffer (1) ; transferrin and $\gamma$-globulins in pH 6.0,0.04, M peak (2); albumin and alpha

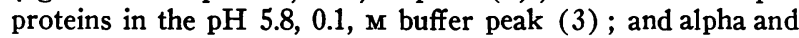
beta arcs along with traces of $\gamma M$ (arrow) in peak 4 eluted with $\mathrm{pH} 5.5,0.3$, $\mathrm{m}$ phosphate buffer. Similar 1st and 2nd peak concentrations of cytotoxic activity were documented in all sera (Table I) separated by DEAE-cellulose chromatography. This finding seemed paradoxical since many of the same sera showed cytotoxicity only in high molecular weight gradient fractions.
Sav M Preg.

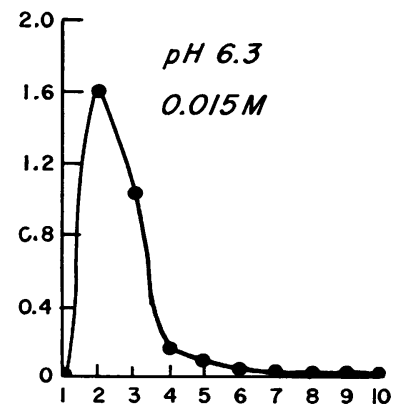

CYTOTOXIC TITER I:32
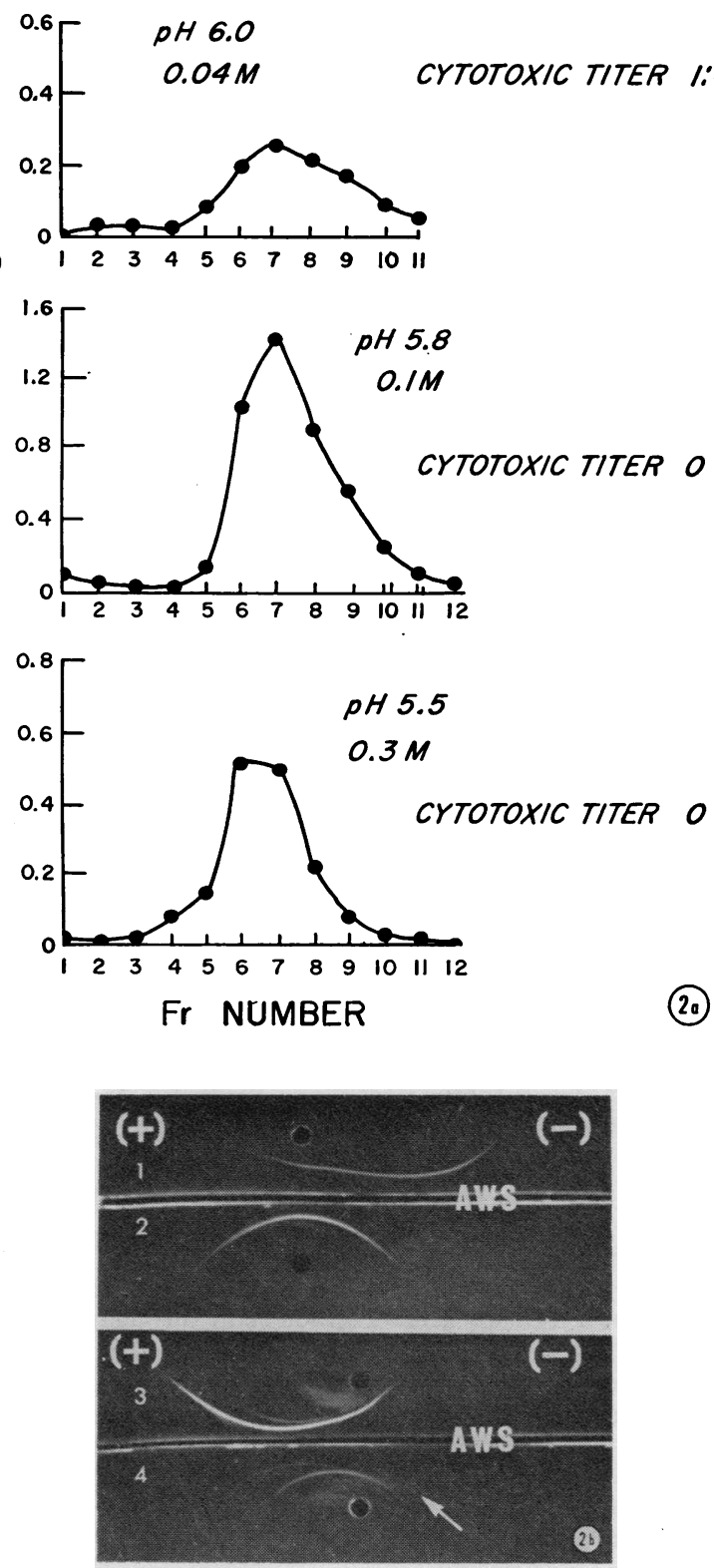

Studies of Human Sera with Cytotoxic Activity 


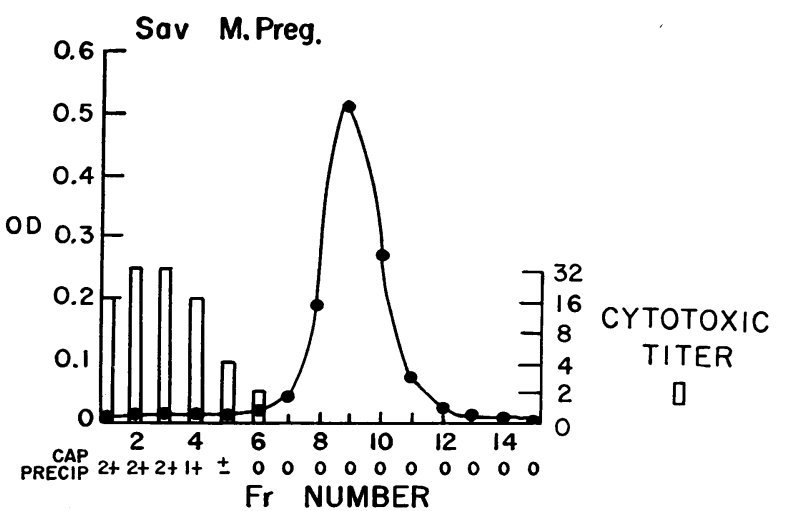

FIGURE 3 Representative sucrose density gradient separation of molecular distribution of cytotoxic activity demonstrable in peak 1 buffer eluate from serum Sav. (shown in Figs. 1 and 2). Peak 1 had been shown to contain the majority of cytotoxic activity and only $\gamma \mathrm{G}$ globulin by immunoelectrophoresis and inhibition of specific tanned cell agglutination reactivity. All cytotoxicity for HL-A 2 test lymphocytes was found in the high molecular weight fractions $1-6$, representing a minority of the $\gamma \mathrm{G}$ globulin applied to the gradient. Monoclonal 19S rheumatoid factor was used as a reagent to test for complexes or aggregates of $\gamma \mathrm{G}$ globulin in gradient fractions and capillary precipitation with test rheumatoid factor corresponded with cytotoxicity as noted in fractions 1-5. Specificity for HL-A 2 test lymphocytes was confirmed by absence of reactivity for other test HL-A cells.

ing or high molecular weight cytotoxic activity. Moreover, if the $7 \mathrm{~S}$ fractions showing cytotoxic activity after gradient separation at acidic $\mathrm{pH}$ were rerun in a neutral medium, the activity appeared once again at the bottom or high molecular weight region of the gradient. Representative experiments showing these findings are

Figure 4 In (A) the first DEAE peak (eluted from Cosk. serum with $\mathrm{pH} 6.3,0.015 \mathrm{M}$ phosphate buffer) was separated by density gradient performed at neutral $\mathrm{pH}$ 7.4. Cytotoxic activity was noted at the bottom of the gradient indicated to the left representing the high molecular weight fractions. When the same first DEAE peak was equilibrated by dialysis with acetate buffer $\mathrm{pH} 4.0$ and separation effected (B) by gel filtration using Sephadex G-200 equilibrated with $\mathrm{pH} 4.0$ acetate buffer, cytotoxic activity was noted in 7S regions. Next, as shown in (C), when the same 7S fractions were taken from separation (B) above and rerun on a density gradient at neutral $\mathrm{pH}$, cytotoxic activity sedimented as high molecular weight materials. However, finally if the 7S fractions from separation (B) above were rerun on density gradient at an acid $\mathrm{pH}$ of 4.0 as in (D), cytotoxic activity was found in $7 \mathrm{~S}$ regions of the gradient (fractions 9-12), after dialysis of fractions back to neutral $\mathrm{pH}$. These experiments were interpreted as indicating that the cytotoxic activity in Cosk. serum was effected by $\gamma \mathrm{G}$ molecules which at neutral pH sedimented as high molecular weight complexes or aggregates but which could be shown to separate within $7 \mathrm{~S}$ regions under conditions of acid milieux. indicated in Fig. 4. These findings were interpreted as most compatible with the hypothesis that high molecular weight cytotoxic activity in such sera was a function of higher molecular weight complexes of molecules of $\gamma \mathrm{G}$ similar to intermediate complexes previously described by Kunkel and others $(12,13)$.

An attempt was next made to confirm that the cytotoxic high molecular weight fractions of gradient separations from initial DEAE peaks were indeed $\gamma \mathrm{G}$ complexes. Rapidly sedimenting gradient fractions from such sera were reacted with monospecific antibody to $\gamma \mathrm{G}, \gamma \mathrm{A}, \gamma \mathrm{E}, \gamma \mathrm{D}$, and $\gamma \mathrm{M}$, and supernates tested for residual cytotoxic activity. Only absorption by anti- $\gamma \mathrm{G}$ antiserum abolished cytotoxic activity in such experiments (Table II). Control experiments revealed no intrinsic cytotoxicity generated by absorbing antisera
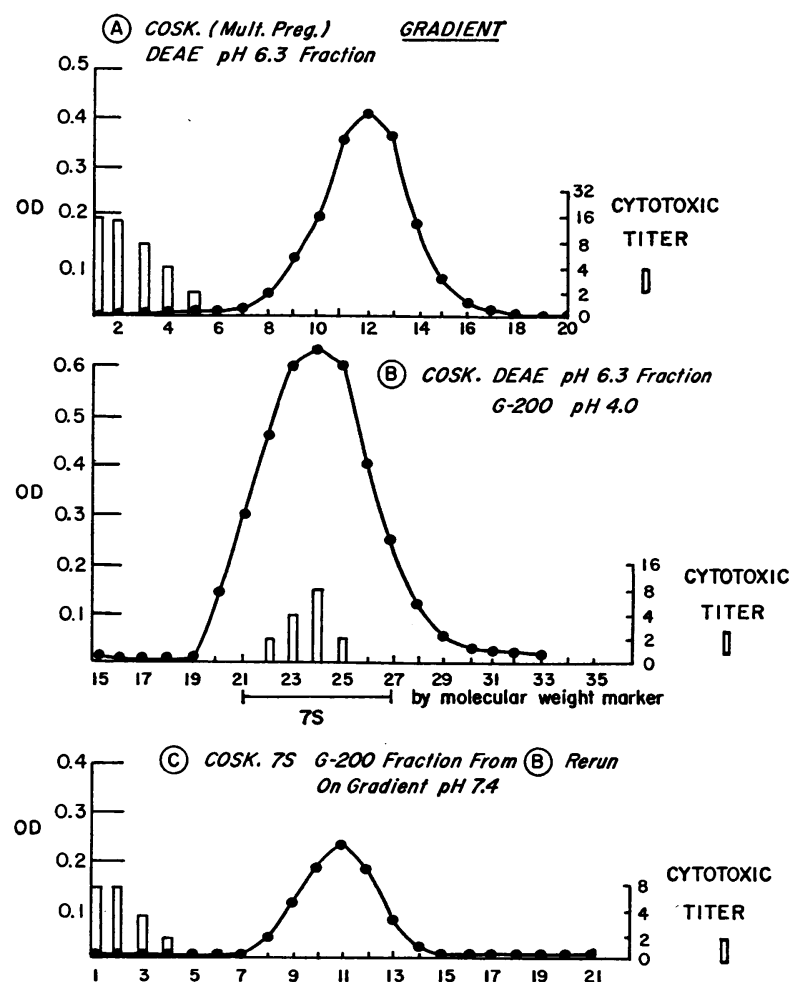

(D) cosk. 75 6-200 Fraction From(B) Rerun On Grodient $\mathrm{PH} 4.0$

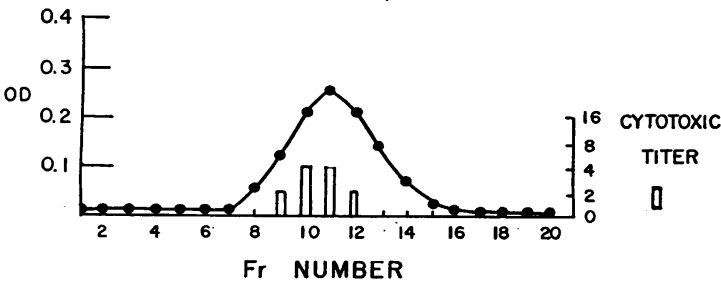


which had been previously absorbed with test lymphocytes but still contained their specificity for the appropriate immunoglobulins.

Moreover, sera shown by gradient analysis to contain primarily high molecular weight cytotoxic activity (Table I) were treated with $0.1 \mathrm{~m}$ mercaptoethanol (10) and tested for cytotoxicity. In all instances, the cytotoxic activity was undiminished by mercaptoethanol treatment. Representative results of such experiments are shown in Table III. It thus appeared that high molecular weight cytotoxic antibody activity, demonstrated in most of the human sera tested, was a function of complexes or aggregates of $\gamma \mathrm{G}$ molecules sedimenting as polymers of high molecular weight. Of considerable interest was the documentation of this phenomenon in five of the human cord sera studied.

Because the behavior of high molecular weight $\gamma \mathrm{G}$ cytotoxic antibodies documented above seemed extremely similar to that previously extensively studied by others $(12-14)$ as intermediate $\gamma \mathrm{G}$ complexes between $7 \mathrm{~S} \gamma \mathrm{G}$ rheumatoid factor and other $\gamma \mathrm{G}$ globulin molecules, we tested four human sera containing large amounts of such $11 \mathrm{~S}-18 \mathrm{~S}$ complexes for intrinsic cytotoxic activity. Three were negative but one was strongly positive. Density gradient separation confirmed predominant high molecular weight cytotoxic activity within this serum taken from a patient with mixed connective tissue disease and hyperglobulinemic purpura (Fig. 5). The possibility still remained that the high molecular weight $\gamma \mathrm{G}$ cytotoxic complexes consisted of complexes of 7S anti-HL-A specific antibody plus molecules of $7 \mathrm{~S} \gamma \mathrm{G}$ rheumatoid factor. Accordingly, all cytotoxic sera or isolated fractions were tested for anti-human $\boldsymbol{\gamma}$-globulin activity using $\mathrm{Rh}$ positive $C D$ human cells coated with incomplete anti-CD antibody Ripley (15). Although many of the sera from the multiply transfused patients were positive for antihuman $\gamma$-globulin antibody by this technique, many strongly cytotoxic sera showed no detectable anti- $\gamma$ globulin antibody. A further test of the above hypothe-
TABLE II

Effect of Absorption of High Molecular Weight Gradient Fractions Showing Cytotoxic Antibody Activity with Anti-Immunoglobulin Antisera

\begin{tabular}{lcccc}
\hline $\begin{array}{c}\text { High molecular } \\
\text { weight gradient } \\
\text { fractions tested } \\
\text { from patient }\end{array}$ & $\begin{array}{c}\text { Titer of } \\
\text { cytotoxicity } \\
\text { before } \\
\text { absorption }\end{array}$ & \multicolumn{2}{c}{$\begin{array}{c}\text { Titer after } \\
\text { absorption with: }\end{array}$} \\
\cline { 3 - 5 } & anti- $\gamma \mathrm{G}^{*}$ & anti- $\gamma \mathbf{M}^{*}$ \\
\hline 1. Lewand. & $1: 16$ & 0 & $1: 16$ \\
2. Tisch. & $1: 32$ & $1: 4$ & $1: 32$ \\
3. Coskr. & $1: 16$ & 0 & $1: 16$ \\
4. K-185 & $1: 32$ & $1: 2$ & $1: 32$ \\
\hline
\end{tabular}

* Absorption with anti- $\gamma \mathrm{A}, \gamma \mathrm{D}$, and $\gamma \mathrm{E}$ produced no change in cytotoxicity titers.

sis was performed by adding insoluble $\gamma \mathrm{G}$, aggregated by ethylchloroformate $(16,17)$ in order to preferentially absorb out $7 \mathrm{~S} \gamma \mathrm{G}$ anti- $\gamma$-globulins which might be active but self-inhibited by other $\gamma \mathrm{G}$ molecules in solution, and therefore incapable of producing agglutination of Ripley-coated cells. Absorption of such sera with insoluble $\gamma \mathrm{G}$ globulin resulted in no diminution of cytotoxic activity.

In order to document the presence of high molecular weight complexes of $\gamma \mathrm{G}$ globulin within isolated serum fractions producing cytotoxic activity, several monoclonal $\gamma \mathrm{M}$ rheumatoid factors were utilized as reagents capable of producing capillary tube precipitation with such complexes or aggregates of $\gamma \mathrm{G}$ globulin (18). Positive confirmation of $\gamma \mathrm{G}$ complexes was obtained using gradient separations of initial DEAE peaks possessing cytotoxic activity (Fig. 3 ).

Studies of human sera containing cold agglutinins. The only exception to the above observations documenting high molecular weight $\gamma \mathrm{G}$ cytotoxicity was the situation encountered among the panel of 15 human cold agglutinin sera studied. The apparent broad cytotoxic antibody activity, demonstrable among this group of sera (Table IV), as well as the striking variability of

TABLE III

Effect of 0.1 м Mercaptoethanol Treatment on Cytotoxic Antibody Activity in Five Representative Sera

\begin{tabular}{|c|c|c|c|c|c|c|c|c|c|c|c|c|c|c|c|c|c|c|}
\hline \multirow{2}{*}{$\begin{array}{l}\text { Reciprocal dil. } \\
\text { of serum }\end{array}$} & \multicolumn{9}{|c|}{ Cytotoxic activity of untreated serum } & \multicolumn{9}{|c|}{ Cytotoxic activity of serum, treated with mercaptoethanol } \\
\hline & $\mathbf{0}$ & 2 & 4 & 8 & 16 & 32 & 64 & 128 & 256 & $\mathbf{0}$ & 2 & 4 & 8 & 16 & 32 & 64 & 128 & 256 \\
\hline \multicolumn{19}{|c|}{ Sera from patients with multiple pregnancy } \\
\hline $\begin{array}{l}\text { 1. Tisch. } \\
\text { 2. Salt. } \\
\text { 3. Sav. }\end{array}$ & $\begin{array}{l}4+* \\
4+ \\
4+\end{array}$ & $\begin{array}{l}4+ \\
4+ \\
4+\end{array}$ & $\begin{array}{l}4+ \\
3+ \\
4+\end{array}$ & $\begin{array}{l}3+ \\
3+ \\
3+\end{array}$ & $\begin{array}{l}3+ \\
2+ \\
3+\end{array}$ & $\begin{array}{l}2+ \\
2+ \\
2+\end{array}$ & $\begin{array}{c}2+ \\
\pm \\
1+\end{array}$ & $\begin{array}{l}1+ \\
0 \\
\pm\end{array}$ & $\begin{array}{l}\mathbf{0} \\
\mathbf{0} \\
\mathbf{0}\end{array}$ & $\begin{array}{l}4+ \\
4+ \\
4+\end{array}$ & $\begin{array}{l}4+ \\
4+ \\
4+\end{array}$ & $\begin{array}{l}4+ \\
3+ \\
4+\end{array}$ & $\begin{array}{l}3+ \\
2+ \\
3+\end{array}$ & $\begin{array}{l}2+ \\
2+ \\
3+\end{array}$ & $\begin{array}{l}2+ \\
1+ \\
2+\end{array}$ & $\begin{array}{l}2+ \\
0 \\
1+\end{array}$ & $0_{ \pm}^{ \pm}$ & $\begin{array}{l}0 \\
0 \\
0\end{array}$ \\
\hline \multicolumn{19}{|c|}{ Sera from patients with cold agglutinins } \\
\hline $\begin{array}{l}\text { 4. Gor. } \\
\text { 5. Sak. }\end{array}$ & $\begin{array}{l}4+ \\
3+\end{array}$ & $\begin{array}{l}4+ \\
3+\end{array}$ & $\begin{array}{l}4+ \\
3+\end{array}$ & $\begin{array}{l}3+ \\
2+\end{array}$ & $\begin{array}{l}3+ \\
2+\end{array}$ & $\begin{array}{l}2+ \\
2+\end{array}$ & $\begin{array}{l}2+ \\
1+\end{array}$ & $\begin{array}{l}1+ \\
1+\end{array}$ & $\begin{array}{l}0 \\
1+\end{array}$ & $\begin{array}{l}\mathbf{0} \\
\mathbf{0}\end{array}$ & $\begin{array}{l}\mathbf{0} \\
\mathbf{0}\end{array}$ & $\begin{array}{l}\mathbf{0} \\
\mathbf{0}\end{array}$ & $\begin{array}{l}\mathbf{0} \\
\mathbf{0}\end{array}$ & $\begin{array}{l}\mathbf{0} \\
\mathbf{0}\end{array}$ & $\begin{array}{l}\mathbf{0} \\
\mathbf{0}\end{array}$ & $\begin{array}{l}\mathbf{0} \\
\mathbf{0}\end{array}$ & $\begin{array}{l}\mathbf{0} \\
\mathbf{0}\end{array}$ & $\begin{array}{l}\mathbf{0} \\
\mathbf{0}\end{array}$ \\
\hline
\end{tabular}

* Designations $4+, 3+, 2+, 1+$, and 0 refer to percentage of test cells showing cytotoxic reactions as indicated in Table IV. 
TABLE IV

Heterogeneity of Cytotoxic Reactivity of 15 Sera Containing Cold

\begin{tabular}{|c|c|c|c|c|c|c|}
\hline $\begin{array}{l}\text { Donor cell tested } \\
\text { HL-A phenotypes }\end{array}$ & $\frac{\text { Bru. }}{1280}$ & $\frac{\text { Hol. }}{2560}$ & $\frac{\text { Gor. }}{256}$ & $\frac{\text { Men. }}{512}$ & $\frac{\text { Pap. }}{640}$ & $\frac{\text { Sak. }}{640}$ \\
\hline 1. $5,9,12^{+}$, LC19 & $+\ddagger$ & $+t+t$ & +++ & ++ & + & 0 \\
\hline 2. $1,7,8$ & + & $++t+$ & ++ & + & $+t+$ & ++ \\
\hline 3. 8,9, LC26 & 0 & 0 & $+t$ & + & + & $+t$ \\
\hline 4. 2 & 0 & + & +++ & 0 & 0 & 0 \\
\hline 5. $3,7,12$ & 0 & $++t$ & + & 0 & $+t$ & $++t$ \\
\hline 6. $1,7,9,12$, LC 25 & + & $+t+t$ & $+t+t$ & 0 & $++t$ & +++ \\
\hline 7. 7,12 & 0 & ++ & ++++ & 0 & 0 & 0 \\
\hline 8. 1,8 & 0 & 0 & +++ & 0 & ++ & ++ \\
\hline 9. $3,7,9$ & 0 & 0 & $++t$ & 0 & ++ & ++ \\
\hline 10. $2,7,8$ & 0 & +++ & +++ & 0 & 0 & ++ \\
\hline 11. $1,2,8, \mathrm{LC} 26$ & ++ & $+++t$ & $+++t$ & ++ & 0 & + \\
\hline 12. $2,5,7,9$ & + & $++t$ & $++t$ & +++ & +++ & + \\
\hline 13. LC19, LC25, LC26 & 0 & ++ & ++++ & 0 & + & ++ \\
\hline 14. $7,12^{+}, \mathrm{LC} 26$ & ++ & +++ & $+++t$ & ++ & $++t$ & ++++ \\
\hline 15. $2,9,12$ & 0 & ++ & $+t+$ & + & + & + \\
\hline 16. $2,9,12, \mathrm{LC} 25$ & 0 & + & $+t+t$ & 0 & 0 & + \\
\hline 17. 2,5, LC 25, LC 26 & ++ & ++ & +++ & 0 & +++ & $++t$ \\
\hline 18. $8, \mathrm{LC} 26$ & 0 & +++ & $+++t$ & +++ & $+t$ & ++ \\
\hline 19. $8, \mathrm{LC} 26$ & 0 & 0 & $+t+t$ & +++ & $++t$ & $++t+$ \\
\hline 20. $1,8,9$ & 0 & + & ++ & 0 & 0 & $\mathbf{0}$ \\
\hline 21. $2,7,12^{+}$, LC19 & 0 & 0 & ++ & 0 & 0 & $\mathbf{0}$ \\
\hline 22. $2,3,5$, LC19, LC25 & 0 & ++ & + & 0 & 0 & 0 \\
\hline 23. $2,8, \mathrm{LC} 25$ & + & ++ & $++t+$ & ++++ & 0 & ++ \\
\hline 24. 5, LC19, LC25 & 0 & +++ & $++t$ & 0 & + & ++ \\
\hline 25. 2,7 & 0 & ++ & +++ & + & 0 & + \\
\hline
\end{tabular}

* Cold agglutinin sera from patients with chronic cold agglutinin disease. Other sera Bru.-Wat. obtained from patients with viral pneumonia.

$\ddagger+$ refers to cytotoxic reaction in $10-25 \%$ of test cells; ++ , in $25-50 \% ;+++50-75 \%$; and ++++ in $75-100 \%$.

reactivity with individual human lymphocytes tested were of interest. Several cold agglutinin sera taken from patients (Gor., Selb., and Per.) showed cytotoxic effects with all of the panel of individual human lymphocytes tested. No clear-cut correlation was noted between cytotoxicity and cold agglutinin titer, since one monoclonal serum Moo. showed almost universal cytotoxic activity but had a cold agglutinin titer of $1: 16$ with human "I" positive cells and monoclonal cold agglutinin sera Tu. and Viv. with extremely high anti-"I" cold agglutinin titers $(1: 128,000)$ showed very little cytotoxic activity. Furthermore, two monoclonal cold agglutinins with primary anti-" $i$ " specificity sera, not shown in Table IV, also produced cytotoxic activity with a broad panel of test lymphocytes. Density gradient separation of eight cold agglutinin sera showed cytotoxic activity only in $19 \mathrm{~S}$ regions, corresponding to cold agglutinin activity. In all instances, cytotoxic activity was demonstrable in eluates from presensitized human erythrocyte stroma (19) and could also be shown in isolated mono- clonal 19S cold agglutinin obtained by starch block electrophoresis and G-200 exclusion gel filtration. Cold agglutinin eluates from stroma showed only albumin and $\gamma \mathrm{M}$ globulins by immunoelectrophoresis. Treatment of cold agglutinin sera with mercaptoethanol uniformly abolished cytotoxic activity. The cytotoxic antibody activity in such sera thus appeared to be of $\gamma \mathrm{M}$ class since it was mercaptoethanol-sensitive and present in specific antibody eluates. It could also be abolished by absorption of active 19S gradient fractions with specific $\gamma \mathrm{M}$ antiserum.

Studies relating to the possible protective effects of anti-r-globulins. An initial hypothesis which prompted this study was based on the previous reports by others (1-4) of cytotoxic antibody in some patients with connective tissue disorders-disseminated lupus erythematous, rheumatoid arthritis, and periarteritis. Initially it was felt that if such sera contained $\gamma \mathrm{G}$ cytotoxic antibody, autologous cells in such patients might possibly be intrinsically protected by anti- $\gamma$-globulins-19S, $\gamma \mathrm{M}$, 
Agglutinins Tested against a Panel of 25 Individual Lymphocytes

\begin{tabular}{|c|c|c|c|c|c|c|c|c|}
\hline \multicolumn{9}{|c|}{ Anti "I" cold agglu. titer } \\
\hline Selb. & Sel. & Wat. & Cass.* & Gre.* & Moo.* & Per.* & Tu.* & Viv.* \\
\hline 5120 & 2580 & 2560 & 8000 & 16,000 & 16 & 64,000 & 128,000 & 128,000 \\
\hline$++t$ & $+t+$ & + & + & 0 & + & $++t+$ & + & 0 \\
\hline+++ & ++ & +++ & + & 0 & ++++ & $+t+t$ & 0 & 0 \\
\hline+++ & + & 0 & 0 & + & $++t$ & $+t+t$ & 0 & 0 \\
\hline$+t+$ & 0 & 0 & 0 & 0 & $+t+$ & $+++t$ & 0 & 0 \\
\hline$+t+$ & ++ & ++ & + & ++ & $+t+$ & $+t+t$ & 0 & 0 \\
\hline$+t+t$ & $+t+t$ & 0 & + & ++ & ++++ & $+t+t$ & 0 & 0 \\
\hline$+t+$ & + & + & 0 & 0 & $+t$ & $+t+t$ & 0 & 0 \\
\hline$+t+t$ & ++ & 0 & $+t$ & + & $++t$ & $+t+t$ & 0 & 0 \\
\hline$++t+$ & ++ & ++ & $+t+$ & 0 & ++ & $+t+t$ & 0 & 0 \\
\hline$++t+$ & 0 & 0 & 0 & 0 & ++++ & $+t+t$ & 0 & 0 \\
\hline$+t+t$ & ++ & + & $+t+$ & $+t+$ & $+++t$ & $++t+$ & 0 & 0 \\
\hline$++t+$ & + & 0 & ++ & $+t$ & $++t$ & ++++ & 0 & + \\
\hline$+t+t$ & + & + & + & + & +++ & $++t+$ & 0 & 0 \\
\hline$+t+t$ & + & 0 & + & ++ & $+t+t$ & ++++ & 0 & 0 \\
\hline++ & 0 & 0 & 0 & 0 & $+t+$ & ++++ & 0 & 0 \\
\hline++++ & +++ & 0 & + & ++ & $++t$ & $++t+$ & 0 & 0 \\
\hline++++ & 0 & 0 & 0 & 0 & +++ & $++t+$ & 0 & + \\
\hline$++t+$ & $++t+$ & 0 & 0 & + & $+t+$ & $+t+t$ & + & 0 \\
\hline++ & 0 & 0 & 0 & 0 & $++t$ & $+t+t$ & 0 & 0 \\
\hline$+++t$ & 0 & + & 0 & 0 & $+t$ & $+++t$ & 0 & 0 \\
\hline+++ & 0 & + & 0 & 0 & 0 & $++t+$ & 0 & 0 \\
\hline$+t+t$ & + & 0 & 0 & 0 & + & $+t+t$ & 0 & 0 \\
\hline$++t+$ & $++t+$ & ++ & 0 & ++ & ++++ & $++t+$ & 0 & 0 \\
\hline$+++t$ & ++ & ++ & 0 & 0 & +++ & $+t+t$ & 0 & 0 \\
\hline$+++t$ & + & + & + & 0 & $++t$ & $+t+t$ & 0 & 0 \\
\hline
\end{tabular}

$7 \mathrm{~S}, \gamma \mathrm{A}$, or $7 \mathrm{~S} \gamma \mathrm{G}(20-22)$ which might theoretically compete for sites on the Fc portion of $\gamma \mathrm{G}$ cytotoxic antibody and block complement activation and subsequent immune cell lysis. Several experiments were therefore conducted to test this hypothesis. $\gamma$-globulin cytotoxic fractions with well-defined HL-A specificity were isolated from several test sera. Addition of these fractions to appropriate human lymphocytes was performed and incubation at $37^{\circ} \mathrm{C}$ was carried out for $30 \mathrm{~min}$. The presensitized cells were then incubated for $15 \mathrm{~min}$ at room temperature with $19 \mathrm{~S}$ human rheumatoid factors (prepared from whole rheumatoid arthritis sera (23, $24)$ or isolated as monoclonal $\gamma \mathrm{M}$ components from mixed cryoglobulins [25]), and finally exposed to a complement source. In no instance was subsequent lymphocyte lysis or cytotoxic activity impeded. Parallel controls included cell preincubation with cytotoxic $\gamma \mathrm{G}$ antibody, addition of dilutions of specific anti-human $\gamma \mathrm{G}, \gamma \mathrm{A}, \gamma \mathrm{M}$, anti-kappa chain or lambda chain rabbit antisera followed by complement. Neither human nor rabbit anti- $\gamma$-globulins were capable of impeding in vitro cytotoxicity in these experiments. In addition, isolated $\gamma \mathrm{G}$ fractions from patients with rheumatoid arthritis or systemic lupus devoid of intrinsic cytotoxic activity were preincubated with target lymphocytes before addition of cytotoxic antibody, followed by addition of complement source. In no instance did such fractions block cytotoxic effects.

\section{DISCUSSION}

The results presented here clearly indicate that cytotoxic activity in many human sera (from multiply transfused patients, women immunized during pregnancy, patients with subacute bacterial endocarditis, individuals with systemic lupus) as well as in human cord sera often occurs within high molecular weight serum fractions in addition to $7 \mathrm{~S} \gamma$-globulin. That this rapidly sedimenting cytotoxic antibody activity is effected by complexes or aggregates of $\gamma \mathrm{G}$ molecules is of consid- 

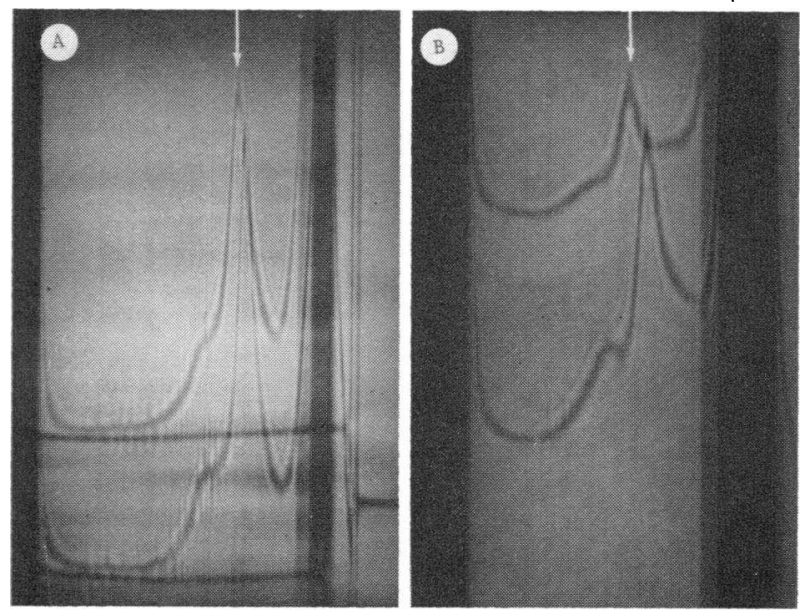

FIgURE 5 Analytic ultracentrifugal patterns of two representative patients showing large amounts of intermediate complexes (11-18S). A. above shows two samples of serum Don. diluted $1: 1$ with normal saline after $48 \mathrm{~min}$ of centrifugation at $59,780 \mathrm{rpm}$. B. pattern shows two serum samples of patient Cor. after $48 \mathrm{~min}$ of centrifugation at the same speed. Sedimentation is from right to left, and 11-18S complexes are marked with arrow. The latter serum showed consistent strong cytotoxic activity with a broad panel of test lymphocytes (multispecific), whereas none was demonstrable in serum Don. Density gradient separation of serum Cor. revealed cytotoxic activity only within high molecular weight fractions, but no demonstrable anti- $\gamma$-globulin activity as tested by agglutination of anti-CD Ripley coated cells.

erable interest, and was apparent when results of gradient separated cytotoxic activity in whole serum were compared with the findings after DEAE chromatographic separation of serum. Abolition of high molecular weight cytotoxic activity by absorption with anti- $\gamma \mathrm{G}$ antiserum as well as resistance of cytotoxic antibody activity to mercaptoethanol treatment produced further confirmation of intrinsic $\gamma \mathrm{G}$ cytotoxic globulins. Dissociation of high molecular weight activity to $7 \mathrm{~S}$ gradient regions in acidic buffers and reassociation to high molecular weight complexes at neutral $\mathrm{pH}$, provided some insight into the protein-protein interactions involved. It is conceivable that since the in vitro method of measuring cytotoxicity involves the addition of an extrinsic complement source, aggregates or complexes of $\gamma \mathrm{G}$ cytotoxic-antibody molecules are most effective in inducing complement activation and subsequent cell death.

Of especial interest was the clear-cut demonstration of high molecular weight $\gamma \mathrm{G}$ cytotoxic antibody complexes in five of nine human cord sera studied. It is not yet clear whether these antibodies passed the placenta or were generated de novo by the fetus. In all positive cord sera studied to date, the pregnancy was the second, third, or more for the mother. No cytotoxic cord serum was found in any primagravida yet tested. Unfortunately, adequate recall and testing of maternal sera have not yet been possible because of unexpected difficulties in recalling mothers for testing, and must await future studies. If the high molecular weight $\gamma \mathrm{G}$ cytotoxic activity in human cord sera originates from maternal blood, one might expect a preferential transport possibly related to $\mathrm{H}$-chain $\gamma \mathrm{G}$ subclass, since Kohler and Farr (26) have shown that transplacental passage of $\gamma \mathrm{G}$ molecules may involve an active transport process.

In the studies recorded here, no correlation was noted between the presence or absence of demonstrable anti$\boldsymbol{\gamma}$-globulins and cytotoxic activity. Furthermore, no in vitro protection against cytotoxicity was afforded with the addition of isolated 19S human anti- $\gamma$-globulins to cytotoxic human $\gamma \mathrm{G}$ antibody and test cells.

The observations recorded here are in many ways compatible with those of Winchester, Agnello, and Kunkel (18) on the high molecular weight complexes of $\gamma \mathrm{G}$ globulin present in the synovial fluids of patients with rheumatoid arthritis. In these latter studies it was shown that $19 \mathrm{~S}$ rheumatoid factor added to high molecular weight $\gamma \mathrm{G}-\gamma \mathrm{G}$ complexes was capable of fixing complement. This parallel observation may explain why our studies have shown no blocking of cytotoxic activity when isolated anti- $\gamma$-globulins were added to the in vitro test system. Moreover, when tested in proper ratios to reactant complexes of $\gamma \mathrm{G}$ globulin it has recently been shown that anti- $\gamma$-globulins are capable of activating the complement sequence $(27,28)$.

It is of interest that the connective tissue disease patients studied by Yust, Schwartz, and Dreyfuss (4) showed primarily $\gamma \mathrm{G}$ cytotoxic activity as defined by DEAE-cellulose chromatography. No gradient studies were reported in this latter study. Similar $\gamma \mathrm{G}$ localization among several lupus sera have been recorded by Butler, Mittal, Rossen, Sharp, and Lidsky (2). Of considerable interest was the apparent negative correlation of cytotoxicity in the latter series $(1,2)$ to known HL-A antigens, although the recent study by Terasaki et al. (3) appeared to show some specificity for HL-A 11 and Te-54 antigens. Of note in the latter study was the demonstration of autocytotoxins in patients with systemic lupus, using the patients' own lymphocytes as test substrates.

The finding of cytotoxic antibody activity in 4 of 53 patients with subacute bacterial endocarditis is of interest in view of previous studies showing various types of autoantibodies in sera from such patients $(29,30)$. The cytotoxic antibodies in such sera showed broad reactivity with the lymphocyte test panel and could not be explained by previous transfusions or pregnancy in three instances. Unfortunately these sera cannot be tested for autocytotoxicity since all three patients are 
now dead. The association between certain viral infections and apparent production of cytotoxic antibody has recently been emphasized by Terasaki and coworkers (3). It is conceivable that infections may in some way alter circulating or effete lymphocytes so as to cause production of antibody to distorted self-determinants on these cells.

The broad cytotoxicity of many of the panel of cold agglutinin sera studied was a surprising finding. These sera were chosen for study because of the well documented ability of human cold agglutinins to fix complement (31). Though the nature of the "I" erythrocyte antigen is not yet fully known, from the results shown in Table II it seems likely that lymphocytes contain surface determinants that share reactivity with the "Ii" system. Most cold agglutinins studied showed primary anti-I specificity; however, cytotoxic reactions were also noted with monoclonal cold agglutinins showing specificity for "i" cells. Since some of the monoclonal cold agglutinin sera show residual agglutinating activity for erythrocytes at temperatures as high as $28^{\circ} \mathrm{C}$, it is possible that they may function as anti-lymphocyte globulins in the body under adverse climactic conditions or during episodes of Raynaud's phenomena.

In diseases such as systemic lupus or periarteritis nodosa it is conceivable that cytotoxic antibodies capable perhaps of killing autologous circulating lymphocytes might function as autologous immunostats or anti-lymphocyte globulin protecting patients from their own self-destructive, cell-mediated immunity. More work in using autologous systems is required to test this hypothesis. It is hoped that the current demonstration of the peculiar high molecular weight $\gamma \mathrm{G}$ molecular form of many human cytotoxic antibodies may help to elucidate their eventual role in human disorders.

\section{ACKNOWLEDGMENTS}

It is a pleasure to acknowledge the expert secretarial help of Mrs. Shirley McAcy in the preparation of this manuscript.

\section{REFERENCES}

1. Mittal, K. K., R. D. Rossen, J. T. Sharp, M. D. Lidsky, and W. T. Butler. 1970. Lymphocyte cytotoxic antibodies in systemic lupus erythematosus. Nature (London). 225: 1255 .

2. Mittal, K. K., R. D. Rossen, W. T. Butler, J. T. Sharp, and M. D. Lidsky. 1970. Lymphocyte cytotoxic antibodies in systemic lupus erythematosus and other connective tissue diseases. Arthritis Rheum. 13: 338. (Abstr.)

3. Terasaki, P. I., V. D. Mottironi, and E. V. Barnett. 1970. Cytotoxins in disease: autocytotoxins in lupus. $N$. Engl. J. Med. 283: 724.

4. Yust, I., J. Schwartz, and F. Dreyfuss. 1970. A cytotoxic serum factor in polyarteritis nodosa and related conditions. Amer. J. Med. 48: 472.
5. Metzgar, R. S., and H. F. Seigler. 1967. Fractionation studies of human antisera containing leukocyte-agglutinating and cytotoxic isoantibodies. Transplantation. 5: 310 .

6. Terasaki, P. I., and J. D. McClelland. 1964. Microdroplet assay of human serum cytotoxins. Nature (London). 204: 998 .

7. Kunkel, H. G. 1960. Macroglobulins and high molecular weight antibodies. IV. Immunological properties. In The Plasma Proteins. Putnam, F. N., editor. Academic Press, Inc., New York. 292.

8. Sober, H. A., F. J. Gutter, M. M. Wyckoff, and E. A. Peterson. 1956. Chromatography of proteins. II. Fractionation of serum protein on anion-exchange cellulose. J. Amer. Chem. Soc. 78: 756.

9. Kim, Y. B., S. G. Bradley, and D. W. Watson. 1964. Characterization of early $19 \mathrm{~S}$ and late $7 \mathrm{~S}$ immunoglobulins in the mouse. J. Immunol. 93: 798.

10. Anderson, R. K., R. Jenness, H. P. Brumfield, and P. Gough. 1964. Brucella-agglutinating antibodies: relation of mercaptoethanol stability to complement fixation. Science (Washington). 143: 1334.

11. Laurent, T. C., and J. Killander. 1964. A theory of gel filtration and its experimental verification. J. Chromatogr. 14: 317.

12. Kunkel, H. G., H. J. Müller-Eberhard, H. H. Fudenberg, and T. B. Tomasi. 1961. Gamma globulin complexes in rheumatoid arthritis and certain other conditions. J. Clin. Invest. 40: 117.

13. Schrohenloher, R. E. 1966. Characterization of the $\gamma$ globulin complexes present in certain sera having high titers of anti- $\gamma$-globulin activity. J. Clin. Invest. 45: 501.

14. Tomasi, T. B., Jr., H. H. Fudenberg, and N. Finby. 1962. Possible relationship of rheumatoid factors and pulmonary disease. Amer. J. Med. 33: 243.

15. Waller, M., and S. D. Lawler. 1962. A study of the properties of the rhesus antibody (Ri) diagnostic for the rheumatoid factor and its application to Gm grouping. Vox Sang. $7: 591$.

16. Avrameas, S., and T. Ternynck. 1967. Biologically active water-insoluble protein polymers. I. Their use for isolation of antigens and antibodies. J. Biol. Chem. 242: 1651.

17. Ito, K., K. Wicher, and C. E. Arbesman. 1969. Insoluble immunoadsorbents containing $\operatorname{IgE}$ : removal of reaginic activity and subsequent elution. J. Immunol. 103: 622 .

18. Winchester, R. J., V. Agnello, and H. G. Kunkel. 1970. Gamma globulin complexes in synovial fluids of patients with rheumatoid arthritis. Partial characterization and relationship to lowered complement levels. Clin. Exp. Immunol. 6: 689.

19. Williams, R. C., Jr., H. G. Kunkel, and J. D. Capra. 1968. Antigenic specificities related to the cold agglutinin activity of gamma M globulins. Science (Washington). $161: 379$.

20. Chodirker, W. B., and T. B. Tomasi, Jr. 1963. Lowmolecular weight rheumatoid factor. J. Clin. Invest. 42: 876.

21. Heimer, R., and F. M. Levin. 1966. On the distribution of rheumatoid factors among the immunoglobulins. Immunochemistry. 3: 1 .

22. Torrigiani, F., and I. M. Roitt. 1967. Antiglobulin factors in sera from patients with rheumatoid arthritis and normal subjets. Quantitative estimation in different immunoglobulin classes. Ann. Rheum. Dis. 26: 334 . 
23. Messner, R. P., T. Laxdal, P. G. Quie, and R. C. Williams, Jr. 1968. Serum opsonin, bacteria, and polymorphonuclear leukocyte interactions in subacute bacterial endocarditis: anti- $\gamma$-globulin factors and their interaction with specific opsonins. J. Clin. Invest. 47: 1109.

24. Messner, R. P., E. M. Caperton, Jr., R. A. King, and R. C. Williams, Jr. 1969. Interactions among rheumatoid factors, $\gamma \mathrm{G}$ antibodies, lymphocytes, and phagocytes. Ann. N. Y. Acad. Sci. 168: 93.

25. Caperton, E. M., Jr., and R. C. Williams, Jr. 1969. In vivo study of IgM rheumatoid factors from mixed cryoglobulins. J. Lab. Clin. Med. 74: 239.

26. Kohler, P. F., and R. S. Farr. 1966. Elevation of cord over maternal IgG immunoglobulin: evidence for an active placental IgG transport. Nature (London). 210: 1070.

27. Schmid, F. R., and M. J. Rocha. 1968. Complement fixation by IgM antibody (rheumatoid factor): Depend- ence on antigen concentration. J. Lab. Clin. Med. 72: 1014.

28. Schmid, F. R., I. M. Roitt, and M. J. Rocha. 1970. Complement fixation by a two-component antibody system: immunoglobulin $G$ and immunoglobulin $M$ antiglobulin (rheumatoid factor). Paradoxical effect related to immunoglobulin G concentration. J. Exp. Med., 132: 673.

29. Williams, R. C., Jr., and H. G. Kunkel. 1962. Rheumatoid factor, complement, and conglutinin aberrations in patients with subacute bacterial endocarditis. J. Clin. Invest. 41 : 666 .

30. Messner, R. P., T. Laxdal, P. G. Quie, and R. C. Williams, Jr. 1968. Rheumatoid factors in subacute bacterial endocarditis-bacterium, duration of disease or genetic predisposition? Ann. Intern. Med. 68: 746.

31. Rosse, W. F., and J. B. Sherwood. 1970. Cold-reacting antibodies: differences in the reaction of Anti-I antibodies with adult and cord red blood cells. Blood. 36: 28 